\title{
LYZ Gene
}

National Cancer Institute

\section{Source}

National Cancer Institute. LYZ Gene. NCI Thesaurus. Code C150276.

This gene is involved in bacterial cell wall peptidoglycan metabolism. 